Commun. Fac. Sci. Univ. Ank. Series B

V. 45 pp. $35-47$ (1999)

\title{
INVESTIGATION ON GASIFICATION PROPERTIES OF SOLID FUELS
}

\author{
R. KARABULUT, A. SINAĞ, Z. MISIRLIOĞLU, M. CANEL \\ Ankara University Science Faculty Dep. Of Chemistry, 06100 Besevler/Ankara-Turkey
}

(Received May 14,1999; Revised July 16, 1999; Accepted July 20,1999)

\begin{abstract}
In this study, chars obtained at different pyrolysis temperatures, ranging from $400^{\circ} \mathrm{C}$ to $900^{\circ} \mathrm{C}$ were investigated in terms of their ignition temperatures and also rates of gasification reactions with $\mathrm{CO}_{2}$. In addition, specific surface area of the char samples were measured and their dependence on pyrolysis temperature were discussed. A decreasing trend in the reactivities of the char samples obtained between $400-600^{\circ} \mathrm{C}$ was observed. Above $600^{\circ} \mathrm{C}$, however, rates of gasification reactions started to increase again. This may be explained by the chemical and physical changes on the sample surface structure. Ignition temperatures of the char samples, on the other hand, increased with temperature due to lower volatile contents of higher temperature chars. Thermal analysis performed under both nitrogen and oxygen atmospheres, as well as composition analysis and ignition temperatures are in accord with experimental results.
\end{abstract}

\section{INTRODUCTION}

Coal gasification is wieved as an effective way utilizing coal. Increasing interest in coal gasification has brought about a need to understand coal char reactivity.

In addition to their chemical structure, particle size and heat value, the reactivities of coal and char play an important role in gasification and combustion. Reactivity of a solid material can be described as its ability to form gaseous products through heterogenous chemical reactions.

It is well known that the gasification reactivity of chars is strongly dependent on the rank of precursor coal ${ }^{1}$. It has been shown that chars obtained from the same coal under different pyrolysis conditions have different reactivities ${ }^{2-8}$. It is generally claimed that increasing the severity of heat treatment, i.e. increasing the temperature or time of heating, decrease the reactivity of $\operatorname{char}^{9}$. Miura et al ${ }^{10}$ showed 
that as the severity of pyrolysis conditions increases, the reactivity of the char decreases. Radovic et al ${ }^{11-12}$ found that higher pyrolysis temperature and longer residence times led to a decrease in active carbon sites and thereby to a reduction in gasification rate. Weeda et $\mathrm{al}^{13}$ found that, in contrast to was expected as a general trend high temperature treatment of coal chars in an inert atmosphere did not always led to a decrease in reactivity.

In this study, ignition temperatures of different char samples were determined. Rate constants of gasification reactions of chars with $\mathrm{CO}_{2}$ were determined in order to compare their reactivities. In addition, pyrolysis and combustion properties of the chars were also studied by thermal analysis.

\section{EXPERIMENTAL}

\section{Pyrolysis}

Two different commercially available activated coals and chars obtained from carbonization of Zonguldak (north Turkey) bituminous coal were tested in this study. Pyrolysis experiments were performed in a quartz, tubular reactor. The reactor, placed inside a horizontal, temperature controlled furnace, was equipped with inlet and outlet connection for the carrier gas and with a thermocouple well at one end. After placing approximately $50 \mathrm{~g}$ of bituminous coal in the reactor, it was purged with nitrogen for 30 minutes, and heated up to the desired temperature at a rate of $20^{\circ} \mathrm{C} / \mathrm{min}$. It was kept at this temperature under nitrogen flow until tar formation ends. Then, the reactor was removed from the furnace, cooled down to the ambient temperature and weighed to determine the amount of char formed from the original bituminous coal.

\section{Measurement of Ignition Temperatures}

Experimental system for the measurement of ignition temperatures was given in detail elsewhere (Canel et al ${ }^{14}$, Hedden et $\mathrm{al}^{15}$ ).

Ignition temperatures of the samples are obtained at the following experimental conditions:

-amount of sample: $1 \mathrm{~g}$

-heating rate: $10^{\circ} \mathrm{C} / \mathrm{min}$

$-\mathrm{O}_{2}$ flow rate: $20 \mathrm{~cm}^{3} / \mathrm{s}$

-reactor diameter: $24 \mathrm{~mm}$

-height of the sample bed: $15 \mathrm{~mm}$ 


\section{Gasification with $\mathrm{CO}_{2}$}

Experimental system is described elsewhere (Erincin et $\mathrm{al}^{8}$ ), so a brief explanation for the procedure will be provided here. 5 grams of finely grounded char or activated coal sample (particle size ranging from 0.4 to $1.0 \mathrm{~mm}$ ) was placed to the fuel cell on the top of the gasification reactor. After the desired temperature was maintained, char particles were fed by gravity into the reactor, while a constant flow of $\mathrm{CO}_{2}$ was let into the system. $\mathrm{CO}$ formed by the reactions between $\mathrm{CO}_{2}$ and char or activated coal particles, was constantly monitored by IR-CO spectrometer (Hartmann \& Braun Uras 2T) and change in percent $\mathrm{CO}$ was determined. $\mathrm{CO}_{2}$ feed was stopped after 30 minutes and the reactor was cooled down to room temperature for weighing in order to determine the amount of char remained in the reactor.

\section{RESULTS AND DISCUSSION}

\section{Results of Coal and Char Analysis}

The proximate analysis of the bituminous coal, chars and activated coals used commercially for the adsorption of gases and the elemental analysis of bituminuous coal are given in Table 1. The changes in the volatile matter contents of samples with pyrolysis temperature are shown in Figure 1.

Table 1. Analysis of Samples

\begin{tabular}{|c|c|c|c|}
\hline Sample & $\begin{array}{l}\% \text { Moisture } \\
\text { (wt \%) }\end{array}$ & $\begin{array}{c}\% \text { Ash } \\
\text { (wt \%, daf) }\end{array}$ & $\begin{array}{l}\text { Voltaile Matter } \\
\text { (wt \%, daf) }\end{array}$ \\
\hline Bituminous Coal & 1.2 & 9.1 & 27.0 \\
\hline $400^{\circ} \mathrm{C} \mathrm{Char}$ & - & 9.6 & 12.3 \\
\hline $500^{\circ} \mathrm{C}$ Char & - & 12.2 & 11.5 \\
\hline $600^{\circ} \mathrm{C}$ Char & - & 11.8 & 9.4 \\
\hline $700^{\circ} \mathrm{C}$ Char & - & 12.7 & 7.1 \\
\hline $800^{\circ} \mathrm{C} \mathrm{Char}$ & - & 12.3 & 8.6 \\
\hline $900^{\circ} \mathrm{C}$ Char & - & 12.1 & 8.8 \\
\hline $\begin{array}{c}\text { Activated Coal } \\
\left(\mathrm{R}_{1} \text { Extra }\right)\end{array}$ & 20.9 & 4.7 & 2.9 \\
\hline $\begin{array}{c}\text { Activated Coal } \\
\text { (RBAA) }\end{array}$ & 1.8 & 12.6 & 12.4 \\
\hline Bituminous Coal & & \begin{tabular}{cc}
1 & \multicolumn{3}{c}{ Analysis (w } \\
$\mathrm{H}$ & $\mathrm{S}$ \\
5.2 & 0.4 \\
\end{tabular} & \\
\hline
\end{tabular}


As seen from Table 1 and Figure 1 the volatile matter content of chars decrease with increasing pyrolysis temperature, reaching a minimum at $700^{\circ} \mathrm{C}$. Further increase in temperature, results in slightly higher volatile contents due to secondary cracking reactions

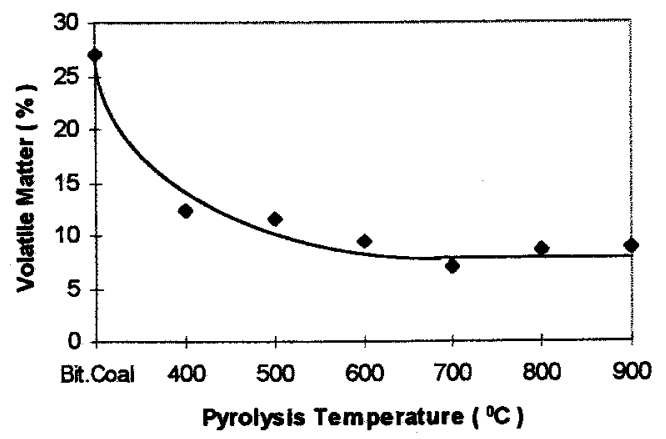

Figure. 1. Volatile matter of samples versus pyrolysis temperature

\section{Thermogravimetric Analysis}

Thermogravimetric studies (TG) and measurements were carried out in a thermobalance (PL-STA $1000 \mathrm{H}$ SETARAM) by recording the weight changes of samples as a function of temperature under nitrogen or oxygen atmosphere to obtain pyrolysis behaviours and burning characters, respectively. The samples were heated from $20^{\circ} \mathrm{C}$ to $900^{\circ} \mathrm{C}$ with a constant heating rate of $15^{\circ} \mathrm{C} / \mathrm{min}$ under $50 \mathrm{~cm}^{3} / \mathrm{min}$ nitrogen or oxygen flow. All experiments were repeated at least twice.

\section{Measurement of Specific Surface Areas of the Char Samples}

Specific surface areas of the samples determined by BET method, through nitrogen adsorption at $-196^{\circ} \mathrm{C}$ are given in Table 2 and the changes in surface area with coking temperature are shown in Figure 2.

Table 2. Specific surface areas of the char samples

\begin{tabular}{|c|c|}
\hline Pyrolysis Temperature $\left({ }^{\circ} \mathrm{C}\right)$ & Surface Area $\left(\mathrm{m}^{2} \mathrm{~g}^{-1}\right)$ \\
\hline 400 & 63.8 \\
\hline 500 & 55.2 \\
\hline 600 & 35.2 \\
\hline 700 & 63.6 \\
\hline 800 & 24.6 \\
\hline 900 & 20.5 \\
\hline Activated Coal ( $\mathrm{R}_{1}$ extra ) & 1621.5 \\
\hline Activated Coal (RBAA) & 1770 \\
\hline
\end{tabular}




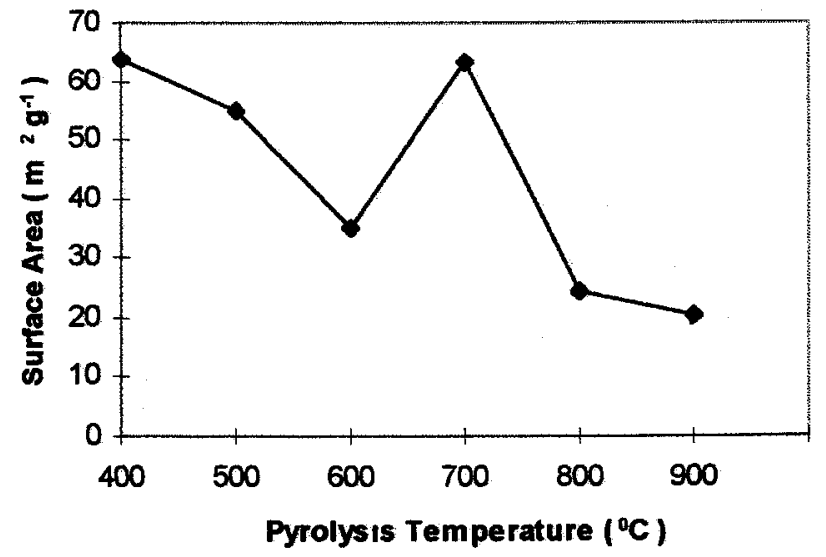

Figure 2 Surface areas of chars versus pyrolysis temperature.

As seen from Figure 2, specific surface area of the samples decrease with increasing carbonization temperatures up to $600^{\circ} \mathrm{C}$. By the further temperature increase to $700^{\circ} \mathrm{C}$ the surface area increases. In the literature, systematic measurements of the changes in internal surfaces for different chars have been made and their dependence on pyrolysis temperature has been measured, for instance by Chiche, Durif and Pregermain ${ }^{16}$ and some results are shown in Figure 3. It can be seen that the surface area passes through a maximum between $650^{\circ} \mathrm{C}$ and $850^{\circ} \mathrm{C}$ depending on the kind of char. However, surface area drops in all cases, when the temperature rises. The changing of surface area with pyrolysis temperature of the chars used in this study is consistent with the literature data. The decreasing of the surface area with pyrolysis temperature at the relative low temperatures may be explained by chemical structure, ash content and composition of the individual coal. The coal ash has especially important effect on the plastic phase and consequently surface characteristic of the char $^{17}$

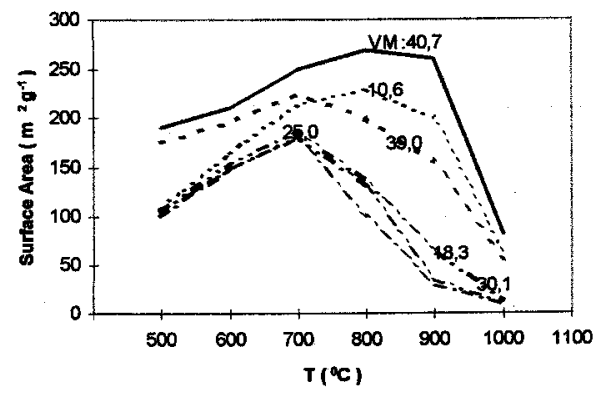

Figure 3 Changes of internal surface area for different chars versus pyrolysis temperature (VM: volatile matter \%) 


\section{Determination of Ignition Temperatures of the Samples}

Ignition temperatures of the samples are presented in Table 3 , and changes of ignition temperatures with pyrolysis temperatures are shown in Figure 4.

Table 3: Ignition Temperatures of the Samples

\begin{tabular}{|c|c|}
\hline Sample & Ignition Temp. $\left({ }^{\circ} \mathrm{C}\right)$ \\
\hline Bituminous Coal & 205 \\
\hline $400^{\circ} \mathrm{C}$ char & 215 \\
\hline $500^{\circ} \mathrm{C}$ char & 239 \\
\hline $600^{\circ} \mathrm{C}$ char & 300 \\
\hline $700^{\circ} \mathrm{C}$ char & 368 \\
\hline $800^{\circ} \mathrm{C}$ char & 360 \\
\hline $900^{\circ} \mathrm{C}$ char & 440 \\
\hline Activated coal $\left(\mathrm{R}_{1}\right.$ Extra) & 388 \\
\hline Activated coal (RBAA) & 190 \\
\hline
\end{tabular}

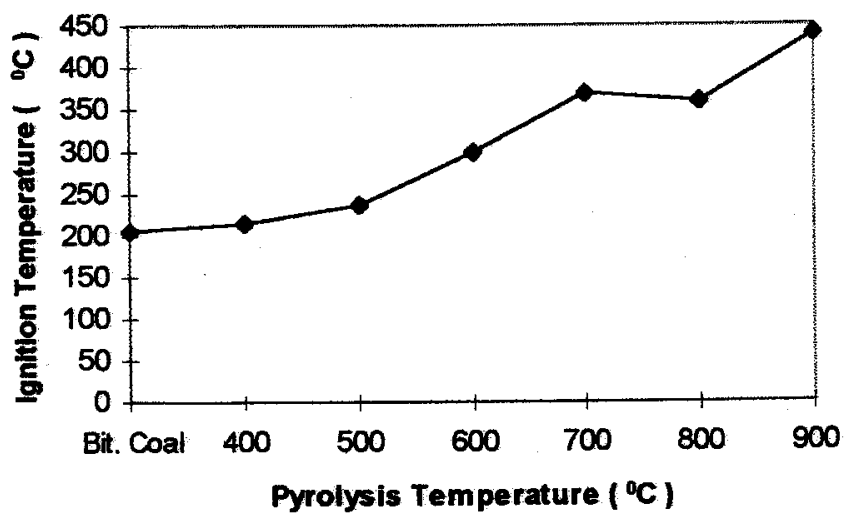

Figure 4 Dependence of pyrolysis temperature on ignition temperature

In the presence of oxygen, generally the evolution of volatile matters takes place first, followed by burning of these volatiles. It is an expected result that chars with higher volatile content will ignite at lower temperatures, considering the fact that volatile matter exist in the coal reacts with oxygen. Furthermore, distortions in 
the pore structure and reduced surface area with increasing temperature will also influence the ignition temperature.

\section{Gasification Results}

Chars obtained from Zonguldak bituminous coal as well as activated coals were reacted with $\mathrm{CO}_{2}$ at different temperatures to determine the reaction rate constants. Figures 5 and 6 present Arrhenius plots of gasification reaction for char obtained at $400^{\circ} \mathrm{C}$ and for activated coal (RBAA), respectively.

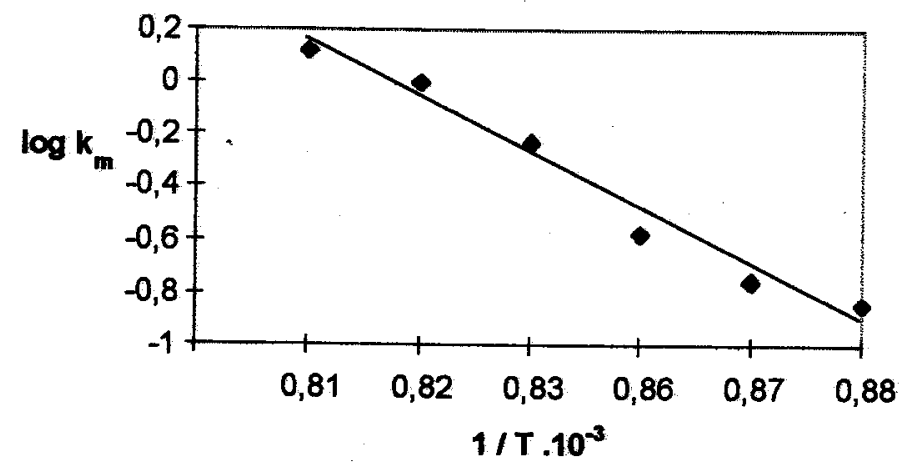

Figure 5 Arrhenius curve for $400^{\circ} \mathrm{C}$ char

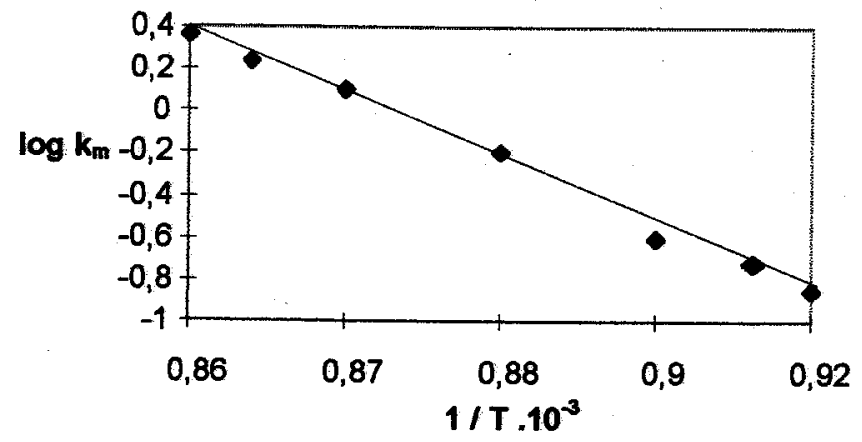

Figure 6 Arrhenius curve for activated coal (RBAA)

$400^{\circ}$ char was reacted with $\mathrm{CO}_{2}$ at $850^{\circ} \mathrm{C}, 870^{\circ} \mathrm{C}, 880^{\circ} \mathrm{C}, 925^{\circ} \mathrm{C}, 940^{\circ} \mathrm{C}$ and $950^{\circ} \mathrm{C}$, and rate constants, $\mathrm{k}_{\mathrm{m}}$, were calculated from the measured $\mathrm{CO}$ contents of the gaseous products. On the other hand, activated coal was reacted at seven different temperatures, ranging from $830^{\circ} \mathrm{C}$ to $910^{\circ} \mathrm{C}$ and results are presented in Figure 6. 
Rate constants calculated at $875^{\circ} \mathrm{C}$ were 0.196 and $1.320 \mathrm{~cm}^{3} / \mathrm{g} . \mathrm{s}$ for the $400^{\circ} \mathrm{C}$ char and the activated coal (RBAA), respectively. Large difference in the rate constants shows that activated coal reacts considerably faster with $\mathrm{CO}_{2}$ than $400^{\circ} \mathrm{C}$ char at the same temperature. This may be related to the origin of the coal and the surface structure.

Surface area and the area of contact with reactant gas in activated coal were much larger. Arrhenius plots for chars and activate coals are presented in Figures 7 and 8 , respectively. The change of gasification reactivity with pyrolysis temperature can be seen from Figure 7.

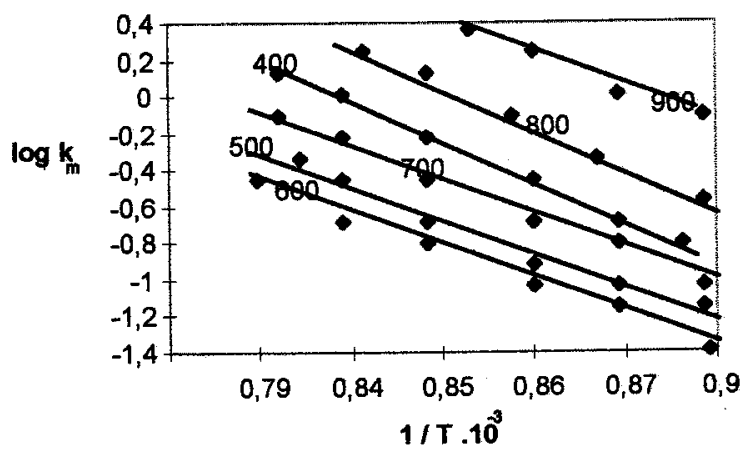

Figure 7 Arrhenius curves for char- $\mathrm{CO}_{2}$ reactions (The numbers on the curves show the pyrolysis temperature)

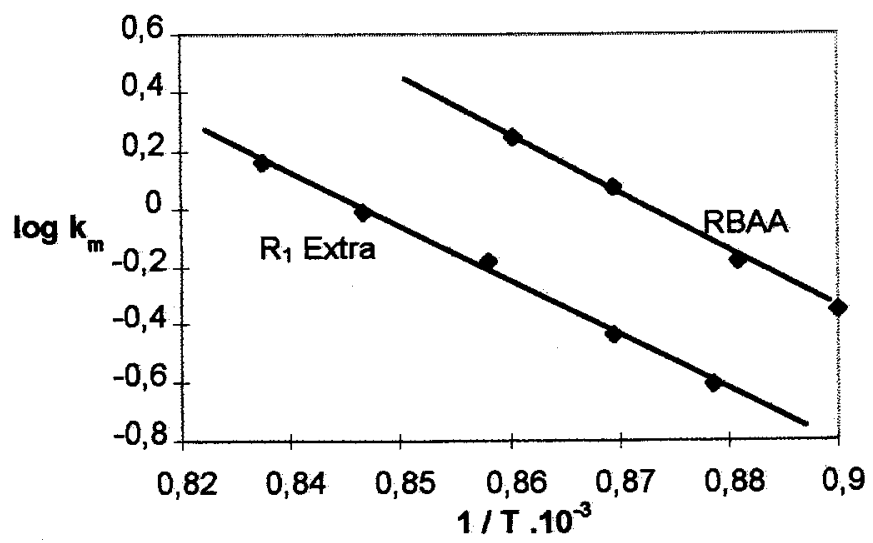

Figure 8 Arrhenius curves for activated coal- $\mathrm{CO}_{2}$ reactions

Initially, the reactivity of the samples decrease with increasing pyrolysis temperature and passes through a minimum around $600^{\circ} \mathrm{C}$. After that it increases 
with pyrolysis temperature. As seen from Figure $7,900^{\circ} \mathrm{C}$ char is the most and the $600^{\circ} \mathrm{C}$ char is the least reactive against $\mathrm{CO}_{2}$. On the other side, activated coal (RBAA) reacts faster with $\mathrm{CO}_{2}$ than the another activated coal $\left(\mathrm{R}_{1}\right.$ Extra) at the same conditions. Both activated coals, however, react with $\mathrm{CO}_{2}$ at lower temperatures than chars. The differences can be explained by the different chemical structure and physical properties of activated coals.

When the gasification reactivities of chars with $\mathrm{CO}_{2}$ (Figure 7) is compared with the surface areas of the chars, any general correlation can't be established between the magnitude of internal surface of a char and its reactivity. The concentration of active sites is more important and their accessibility plays an important role in the rate of the conversion of the solid fuel with the gasifying agent. This has been also emphasized by Radoviç et $\mathrm{al}^{12}$. Knight et al ${ }^{18}$ reported that gasification rate of chars by $\mathrm{CO}_{2}\left(\mathrm{R}_{\mathrm{CO}_{2}}\right)$ increased with decrease \% $\mathrm{C}$. They attributed this to the development of pore structure and the increase of active sites caused by stripping of volatile matter remaining in the char during the initial stage of gasification. Their observation was supported by a good correlation between $\mathrm{R}_{\mathrm{CO}_{2}}$ and the amount of volatile matter remaining in the char. They also reported that $\mathrm{R}_{\mathrm{CO}_{2}}$ increased with increase in heating rate used to prepare the char. Higher heating rates seemed to increase the number of active sites by depressing the development of graphite-like structure.

\section{Result of Thermal Analysis}

In order to investigate the heating behaviours of chars obtained at different pyrolysis temperatures under nitrogen atmosphere, the $400^{\circ} \mathrm{C}$ char and $800^{\circ} \mathrm{C}$ char are chosen as examples, and TG curves have been given in Figure 9 and Figure 10, respectively.

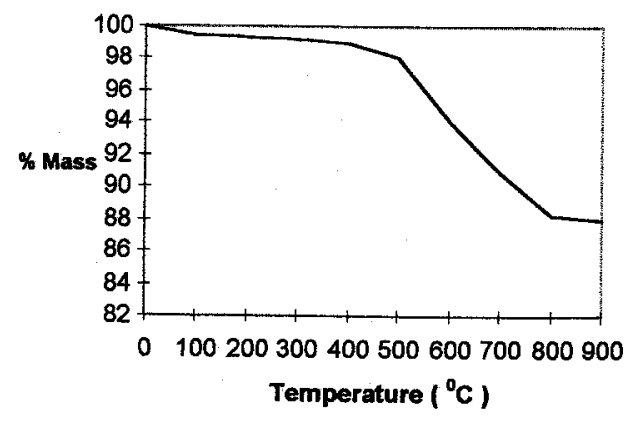

Figure 9 TG curve for $400^{\circ} \mathrm{C}$ char in $\mathrm{N}_{2}$ 


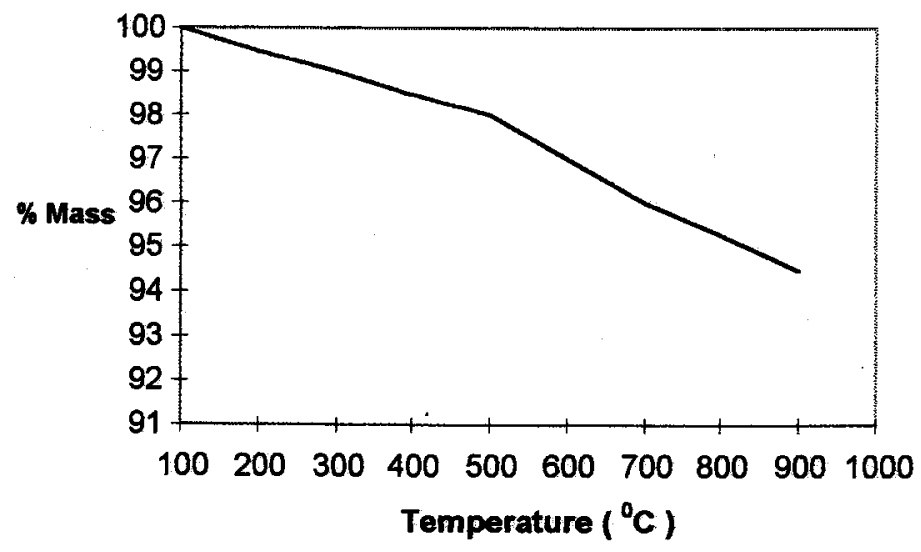

Figure $10 \mathrm{TG}$ curve for $800^{\circ} \mathrm{C}$ char in $\mathrm{N}_{2}$

For both samples mass loss was observed with increasing the temperature due to removal of volatile matter from the coal matrix. Although, slight degradation (1-2 $\%$, by mass) was observed until $500^{\circ} \mathrm{C}$, coal matrix started to rapidly decompose above this temperature. At the final temperature the mass loss for the $400^{\circ} \mathrm{C}$ char was $12 \%$, while it was only $\% 6$ for the $800^{\circ} \mathrm{C}$ char. For the $500^{\circ} \mathrm{C}, 600^{\circ} \mathrm{C}$ and $700^{\circ} \mathrm{C}$ chars mass losses were $11 \%, 10 \%$ and $5 \%$, respectively.

Figures 11 and 12 show TG and DTG (differential thermogravimetric analysis) plots for the combustion of $400^{\circ} \mathrm{C}$ and $800^{\circ} \mathrm{C}$ chars.

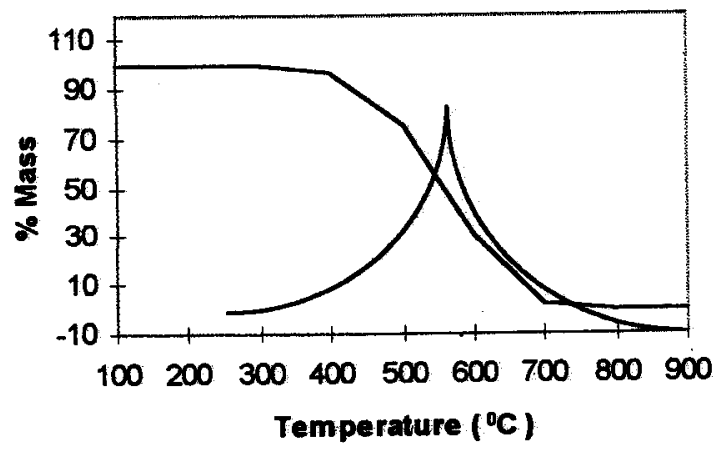

Figure $11 \mathrm{TG}$ and DTG curves for $400^{\circ} \mathrm{C}$ char during combustion 


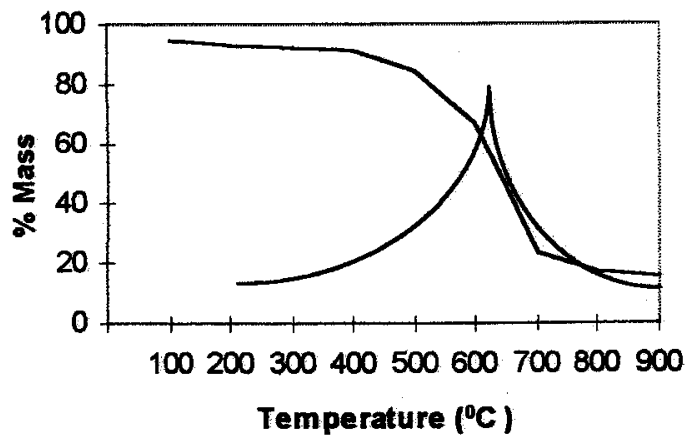

Figure $12 \mathrm{TG}$ and DTG curves of $800^{\circ} \mathrm{C}$ char during combustion

As seen from Figure 10 any significant reaction was not observed between the sample and the oxygen until $400^{\circ} \mathrm{C}$. Combustion takes place between $400^{\circ} \mathrm{C}$ and $700^{\circ} \mathrm{C}$ and $9 \%$ ash remains at $700^{\circ} \mathrm{C}$. Thus, this range can be taken as the burning range of the $400^{\circ} \mathrm{C}$ char. The largest mass loss occurs about $595^{\circ} \mathrm{C}$. On the other hand, $800^{\circ} \mathrm{C}$ char starts to react with $\mathrm{O}_{2}$ at about $420^{\circ} \mathrm{C}$ and almost $12 \%$ ash remains as residual. DTG plot for the $800^{\circ} \mathrm{C}$ char gives a maximum at $630^{\circ} \mathrm{C}$.

Table 4 presents the peak values for the combustion of chars and activated coals in thermal analysis.

Table 4 Temperatures of the peaks of DTG curves

\begin{tabular}{|c|c|}
\hline Sample & Ignition Temp. $\left.{ }^{\circ} \mathrm{C}\right)$ \\
\hline $400^{\circ} \mathrm{C}$ char & 595 \\
\hline $500^{\circ} \mathrm{C}$ char & 615 \\
\hline $600^{\circ} \mathrm{C}$ char & 630 \\
\hline $700^{\circ} \mathrm{C}$ char & 640 \\
\hline $800^{\circ} \mathrm{C}$ char & 630 \\
\hline $900^{\circ} \mathrm{C}$ char & 675 \\
\hline Activated coal $\left(R_{1}\right.$ Extra) & 660 \\
\hline Activated coal (RBAA) & 460 \\
\hline
\end{tabular}

These temperatures provide a good comparison for the burning properties of the samples. Similar results were also reported elsewhere ${ }^{19}$. When compared the data presented in Table 4 to those in Table 3, the order in ignition temperatures is the same with the temperatures of the peaks obtained by thermal analysis. Burning 
conditions and the sample amounts are different in thermal analysis and in ignition experiments. Therefore, amount of heat generated and mechanism at which heat is transferred are also different, causing slight changes in ignition temperatures, obtained by these two techniques.

\section{RESULTS}

The reactivity of chars in gasification with $\mathrm{CO}_{2}$ is influenced by the pyrolysis conditions. The temperature treatment has considerable influence on the physical structure of coals. The experimental results show a decrease of reactivity in $\mathrm{CO}_{2}$ with increase in final pyrolysis temperature up to $600^{\circ} \mathrm{C}$. Beyond this temperature the reactivity increases by further increase in final pyrolysis temperature. factors:

The gasification reactivity is usually considered to depend on the following

-the accessibility of the char to the reactant gas,

-the concentration of the carbon active sites.

It can be concluded that increasing the pyrolysis temperature up to $600^{\circ} \mathrm{C}$, decrease the reactivity of char due to the process of thermal annealing which is thought to involve a combination of micropore collapse, structural ordering of the carbon on a molecular level. By further increase in final pyrolysis temperature, the heat treatment destroys the dislocations in the crystalline structure, which are believed to give rise to the active sites on char surfaces ${ }^{20}$. Due to the increasing of active sites concentration the higher reactivity of chars occurred in the temperature range investigated.

Ignition temperatures of the samples obtained by two different approach are compared. Although, there exist slight differences, in absolute values. The order and the trend were exactly the same for two techniques. This shows that reactivities of solid fuels can be determined by ignition experiments without a need for expensive equipments. In addition, the amount of ash from thermal analysis is also in agreement with that obtained by standard techniques.

It has been showed that TG and DTG plots obtained by heating the samples under nitrogen or oxygen atmospheres, provide valuable information about the burning ranges and thermal degradation characteristic of the samples. Decrease in surface areas and increase in ignition temperatures are consistent with increasing pyrolysis temperatures.

Finally, ignition temperature is an indication of burning tendency, and rate constant obtained from reactions with $\mathrm{CO}_{2}$ is a measure of gasification tendency for 
solid fuels. For the comparing of the reactivities of different solid fuels, the experiments have to be performed with same equipment under the same conditions.

\section{REFERENCES}

[1] Jenkins, R.G., M Nandi, S.P., Walker, P.L.Jr. Fuel 1973,52,288

[2] Hippo, E.J., Walker P.L.Jr. Fuel 1975, 54, 245

[3] Mc Carthy, D.J. Carbon 1981, 19, 297

[4] Nandi, S.P., Johnson, J.L., ACS Preprints, Div. Fuel Chem. 1979, 24(3),17

[5] Ljubisa, R.R., Walker P.L.Jr., Jenkins, R.G. Fuel 1983, 62, 849-856

[6] Mithilesh, K., Gupta. R.C., Fuel 1994, 73, 1922-1925

[7] Canel, M., Hedden, K. Erdöl und Kohle, Erdgas-Petrochemie 1985,38(1),26-30

[8] Erincin, D., Sınağ, A., Mısırlığlu, Z., Canel, M. European Coal Conference' 97,5-10 May 1997, İzmir-Turkey (accepted for publishing)

[9] Samaras, P., Diamodopoulos, E., Sakellaropoulos, G.P., Fuel 1996, 75, 1108-1113

[10] Miura, K., Hashimoto, K., Silveston, P.L., Fuel 1989, 68, 1461

[11] Radovic, L,R., Walker, P.L.Jr., Jenkins, R.G., Fuel 1983, 62, 609

[12] Radovic, L.R., Walker, P.L.Jr., Jenkins, R.G., Fuel 1983, 62,849

[13] Weeda, M., Ermers, F., v.d. Linden, B., Kaptejin, F., Moulijn, J.A. Fuel Process. Techno. $1993,36,243$

[14] Canel, Z., Canel, M. And Sarıkaya, Y. Fuel, 1994, 73,5,656-659.

[15] Hedden, K., Wilhelm, A., Ger. Chem. Eng., 3, No: 2,89-95, Germany. 1980

[16] Chicke, P., Durif, S., Pregermain, S., Fuel, 1965, 44,5

[17] Predeanu, G. And Albastroiu, P. Proc. $9^{\text {th }}$ Int. Conf. On Coal Science, 7-12 Sept. 1997, Essen, Vol. 2, 877-880.

[18] Knight, A.T. and Sergeant, G.D. Proc. Of $3^{\text {rd }}$ PACHEC, Vol. 3, Seoul, 1983, p. 236

[19] Tartarelli, R., Giorgini, M., Ghetti P., Belli, R. Fuel, 1987, 66, 1737-1738.

[20] Van Heek K.H. and Mühlen H.J., Fuel Process. Technol., 1987, 15,113-133 